\title{
The inclusion of 'outsiders' by Japanese unions? The organizing of non-regular workers in retail
}

DOI:

$10.1177 / 0950017018759205$

\section{Document Version}

Accepted author manuscript

Link to publication record in Manchester Research Explorer

\section{Citation for published version (APA):}

Keizer, A. (2018). The inclusion of 'outsiders' by Japanese unions? The organizing of non-regular workers in retail. Work, Employment \& Society, 33(2), 226. https://doi.org/10.1177/0950017018759205

\section{Published in:}

Work, Employment \& Society

\section{Citing this paper}

Please note that where the full-text provided on Manchester Research Explorer is the Author Accepted Manuscript or Proof version this may differ from the final Published version. If citing, it is advised that you check and use the publisher's definitive version.

\section{General rights}

Copyright and moral rights for the publications made accessible in the Research Explorer are retained by the authors and/or other copyright owners and it is a condition of accessing publications that users recognise and abide by the legal requirements associated with these rights.

\section{Takedown policy}

If you believe that this document breaches copyright please refer to the University of Manchester's Takedown Procedures [http://man.ac.uk/04Y6Bo] or contact uml.scholarlycommunications@manchester.ac.uk providing relevant details, so we can investigate your claim.

\section{OPEN ACCESS}




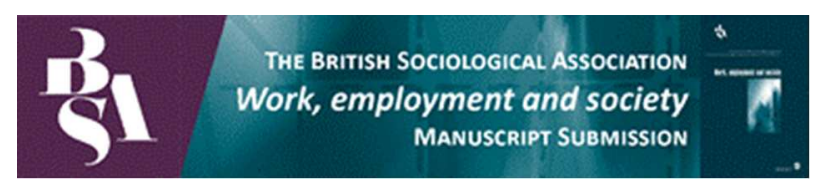

\section{The inclusion of 'outsiders' by Japanese unions? The organizing of non-regular workers in retail}

\begin{tabular}{|r|l|}
\hline Journal: & Work, Employment and Society \\
\hline Manuscript ID & WES-Dec-2016-ARTC-425.R2 \\
\hline Manuscript Type: & Original Manuscript \\
\hline Keywords: & $\begin{array}{l}\text { dualism, inclusion, Japan, non-regular, organizing, part-time, revitalisation, } \\
\text { unionization, unions }\end{array}$ \\
\hline
\end{tabular}

SCHOLARONE ${ }^{\text {M }}$

Manuscripts 


\title{
Inclusion of 'outsiders' by Japanese unions? The organizing of non-regular workers in retail
}

\section{Arjan B Keizer, University of Manchester, UK}

\begin{abstract}
A strong rise in non-regular employment has posed a major challenge to Japanese trade unions which have long limited membership to regular employees. However, a number of mainstream unions in the retail industry have responded by organizing non-regular workers. The article draws on a series of semi-structured interviews with union representatives to analyse the initiatives by the industrial federation UA Zensen and three affiliated enterprise unions. It addresses the implications for both the workers and the unions concerned. Unions have provided a stronger voice to nonregular workers and negotiated better working conditions. However, it has not brought material equality with regular workers or major changes to Japanese unionism. Instead, the enterprise-based and cooperative nature of unionism has shaped the initiatives and reproduced traditional equilibria and processes between labour and management, thus constraining the ability of unions to develop a strong stance for the emancipation of non-regular workers.
\end{abstract}

Keywords: dualism, inclusion, Japan, non-regular, organizing, part-time, revitalisation, unionization, unions

\section{Corresponding author details:}

Arjan Keizer, Alliance Manchester Business School, Booth Street East, Manchester, M15 6PB, UK. Email: arjan.keizer@mbs.ac.uk 


\section{Introduction}

The strong rise in non-regular and often precarious employment has posed major challenges to trade unions across developed economies (e.g. Gumbrell-McCormick, 2011; Hyman, 1997; Keune, 2013). They are increasingly trying to represent these workers but former strategies of exclusion and the inherent characteristics of much non-regular work has hindered progress. This challenge also holds for Japan where inclusion is often restricted by the prevalence of enterprise unions and their exclusive commitment to regular workers (seishain) as members of the firm 'community' (Jeong and Aguilera, 2008; Urano and Stewart, 2007; Weathers, 2010). Japanese unions have therefore been argued to contribute to the existing labour market dualism rather than to its solution (e.g. Broadbent, 2008; Stewart, 2006; Urano and Stewart, 2009).

The challenge has become particularly pressing because of the very strong rise in nonregular (part-time, temporary, agency) employment (hiseiki koyō) in Japan to over one-third of total employment (JILPT, 2016). It has contributed to a historically low unionization rate of 17.3 per cent in 2016 (Survey on Trade Unions Structure) and pushed unions to reconsider their former strategy of exclusion. Moreover, it has raised concerns about the rise in 'working poor' (wākingu puā) and social inequality (kakusa shakai) (e.g. Imai, 2011; Weathers, 2010; Yun, 2010). A limited number of mainstream unions have responded by recruiting and representing non-regular workers and this article analyses the strategies by the industrial union UA Zensen - the most successful federation in this respect - and three of its affiliated enterprise unions at major retail firms. The article will qualify these strategies as 'organizing' but uses this term in a generic sense to refer to the recruitment of new members, similar to Hurd's (2004: 7) definition of 'external organizing', unless explicitly stating otherwise. The focus is on part-time workers, a group that should still be considered 'non-regular' in Japan as its conditions remain fundamentally different to those for regular employees (Keizer, 2008).

The specific character of Japanese unionism makes these initiatives particularly interesting from a comparative point of view. The dominance of enterprise unions has not only resulted in a highly decentralized pattern of collective bargaining but has also shaped cooperative relations with 
management and diminished the need to actively recruit members. These aspects have had an impact on the strategies towards non-regular workers but also indicate how their inclusion can have important implications for both Japanese unionism and the position of these workers. The article finds that the organization of non-regular workers has indeed provided them with a stronger voice towards management, representation during the annual shuntō collective bargaining, and better career and pay conditions. However, it has not resulted in the achievement of material equality between regular and non-regular workers nor has it brought major changes to Japanese unionism. Instead, the specific characteristics of industrial relations and Japanese unions as enterprise-based and cooperative have shaped outcomes to an important extent. It will be argued that organizing has been functional to the reproduction of the traditional 'equilibria' and processes between labour and management without the transformation typical - at least in principle - of many revitalization attempts (Carter, 2000).

The article continues with a brief discussion of the recent comparative literature on union action towards non-regular workers before discussing the character of non-regular employment and unionism in Japan. After a description of the study design, it discusses the strategies as developed by UA Zensen and its affiliated unions in recruiting and representing non-regular workers. The subsequent section addresses the article's two main questions by discussing the implications of the current strategies for the position of non-regular workers and the character of Japanese unions. The article ends with some concluding comments on the future potential of these initiatives.

\section{Trade unions and non-regular employment}

Awareness has grown that trade unions have largely failed non-regular workers, especially those in more precarious employment types (e.g. TUC, 2008). Opposition against inferior working conditions, the threat to secure jobs and the perception of competing interests between regular and nonregular workers have often informed a strategy of exclusion (e.g. Heery, 2009). Both the temporary character of much non-regular employment and its relative prevalence in poorly organized sectors 
tend to limit the possibilities to reach workers who may also fear that unionization negatively affects their future employment opportunities. Moreover, unions may be reluctant to invest their resources because of high membership turnover and concerns that engagement can legitimize precariousness as they often have to accept sub-standard working conditions in order to achieve progress (Grimshaw et al., 2016).

The latter aspect indicates another fundamental challenge to those unions that organize non-regular workers. Any attempt to achieve material equality (Cockburn, 1989) needs to consider the different labour market realities that the various groups face (Heery, 2009). It requires unions to develop a 'coherent and integrated programme of interest representation' that 'reconciles differences of situation and interest' (Hyman, 1997: 520-1). The need to develop such solidarities is not new (e.g. Hyman, 1999; Simms, 2012) but segmented labour markets make it particularly challenging as unions need to develop a response that both addresses the inequalities in the labour market and unites the different constituencies among their members. A perceived failure to do so has informed criticism that unions have contributed to labour market segmentation by consenting to increased labour market flexibilisation for 'outsiders' in non-regular employment while or in return for upholding protection for their 'insider' members in regular employment (e.g. Rueda, 2005; Standing, 2011). In engaging with this debate, Palier and Thelen (2010) have shown the need to separate intentions from outcomes as segmentation can result from unions' weakened position rather than any explicit strategy, with segmentation 'a second-best option for unions that do not have the strength...to protect all workers' (Pulignano et al., 2015: 821).

The revitalisation literature has shown how unions have come to actively recruit and represent those in non-regular employment. These attempts have often inspired a move towards 'organizing', a concept characterized by diverse definitions and a topic of a rather complex academic debate (e.g. Carter, 2006; De Turberville, 2004; Simms, 2012; Simms and Holgate, 2010). The introduction already referred to the important distinction by Hurd (2004) between 'internal organizing', mobilising activities within unionised workplaces, and 'external organizing', the 
recruitment of new members. However, these dimensions have often been grouped together in both the academic debate and union practices (Connolly et al., 2017). As pointed out by Heery (2002: 27), organizing has also been defined by the attempt to be more 'inclusive in scope' by targeting non-union companies and workers at the 'rough end of the labour market'. In accordance with these aspects, organizing tends to imply a transformation of trade union structures and approaches trough self-organization and direct participation (Carter, 2000). However, the literature has pointed out how it has often resulted in top-down initiatives, solely aimed at recruiting members (Simms and Holgate, 2010) to strengthen representation and bargaining (Heery, 2002).

The comparative literature has underlined how union choices towards organizing, and other 'revitalisation' strategies, depend on important differences in employment types, institutional context, state policies, and employer strategies (Frege and Kelly, 2003), which give cause to specific 'sticking points' in the unions' responses (Locke and Thelen, 1995: 342). Organizing, in particular, has been embraced in situations of declining union density and institutional power (GumbrellMcCormick and Hyman, 2013) rather than cases where unions maintain a strong institutional position (Baccaro et al., 2003; Marino, 2012). Several studies have also underlined how the 'identity' of trade unions provides a 'root structure' (Hodder and Edwards, 2015: 847) that shapes both strategies of inclusion and, in turn, their specific organizational form (e.g. Hyman, 2001; Marino, 2012). For example, industrial unionism tends to pursue solidaristic policies for the widest possible group of workers while enterprise unions tend to focus on the companies' core workforce (Benassi and Dorigatti, 2014). The next section will illustrate the relevance of these considerations to the Japanese context by discussing important labour market and union characteristics.

\section{Labour market dualism in Japan and the position of trade unions}

The rise in non-regular employment in Japan has been particularly strong since the early 1990 s as firms responded to difficult economic circumstances (Keizer, 2010). The most prevalent groups part-time workers, arubaito (further part-time jobs for a relatively small number of hours) and 
contract workers - accounted for respectively 18, eight and eight per cent of total employment in 2014 (JILPT, 2016: 28). Many part-timers work long hours, sometimes more than 35 hours a week, and are considered part of the core workforce, albeit as 'permanent employees with inferior occupational status (and pay)' (Gadrey et al., 2001: 175). It has inspired qualifications such as 'quasi part-timers' (Passet, 2003: 177), 'core part-time workers' and 'fulltime part-time workers' (Tsuchida, 2004: 31, 33).

The main factor behind this strong rise has been the substantially lower wages for nonregular and part-time workers in particular (see e.g. JILPT, 2005). It is reflective of a strong labour market dualism constituted by the 'closure' of internal labour markets because of the practice of lifetime employment. This means that the recruitment of regular employees tends to be limit to recent graduates or certain employees during the early years of their career (Keizer, 2008, 2010). Moreover, regular jobs often imply heavy workloads, long hours of overtime and potential geographical relocation (tenkin). These aspects mean that many employees have little choice but to opt for non-career oriented regular jobs and increasingly non-regular employment in spite of its low levels of pay and poor career opportunities. The choice for part-time employment by married women is further promoted by the tax and insurance system and family allowances that firms provide to their regular employees. They offer important advantages to 'dependents' but these are lost or phased out when married women earn more than a certain amount (Nagase, 2003). The same advantages do not extend to unmarried and male workers and the rise in non-regular employment has been particularly problematic for many young workers. Allison (2012: 96) refers to them as a 'lost generation', also because the lack of regular employment limits their opportunities to get married and have children.

Japanese unionism has been criticised for its inability to respond to these developments. A first major issue concerns the dominance of enterprise unions. They are affiliated to industrial federations and national confederations but keep the major share of union dues, provide the majority of officials and hold the main decision making powers within the overall union structure 
(Jeong and Aguilera, 2008). This dominance has strongly shaped the identity of Japanese unionism as the enterprise unions are known for their strong cooperation with management out of the mutual understanding that they 'are in the same boat and the survival or prosperity is the ultimate goal' (Suzuki, 2004: 15). It produces a structurally embedded form of 'partnership' as illustrated by aspects like the mutual recognition of competing and shared interests and the exchange of employment security for commitment and loyalty (e.g. Heery, 2002). Close relations between management and union officials, with union posts often a stepping stone to managerial posts or taken by lower-ranking managers, cement this understanding. It explains why unions have been criticized for colluding with management (Royle and Urano, 2012).

In accordance with this structure and identity, membership has long been limited to the regular workforce. Moreover, membership is often almost complete as union shop agreements tend to imply that joining is 'a fairly automatic and natural action' (Tachibanaki and Noda, 2000: 27). Nonregular workers, instead, were not considered potential members but 'outsiders' to the firm community and an employment buffer that supports survival during difficult times (Jeong and Aguilera, 2008; Urano and Stewart, 2007; Weathers, 2010). The unionization rate among non-regular workers, a mere 2.5 per cent as late as 1999, is indicative (JILPT, 2005: 21). It explains why Urano and Stewart (2009: 128, 136) see Rengo, the main national confederation, and its affiliates as 'unlikely vehicles for alternative strategies' because of their 'exclusionary ideology bound by the perpetuation of the cultural milieu of the secure work force'. The unions are considered 'part responsible, part prisoners' of the existing employment framework (Stewart, 2006: 69) and supportive of its 'gender compromise' (Gottfried and Hayashi-Kato, 1998: 41).

The organization of non-regular workers has instead been the prerogative of alternative unions like women-only and, in particular, community unions which organize workers from different firms within a certain region (e.g. Broadbent, 2008; Oh, 2012; Stewart, 2006; Suzuki, 2008; Urano and Stewart, 2007, 2009; Weathers, 2010). Well-known examples include the Edogawa union from 1994, the Tokyo Managers Union from 1993 and the Women's Union Tokyo from 1995 (Oh, 2012; 
Royle and Urano, 2012). The rise in non-regular employment provides these unions with a large pool of potential members. However, they face important challenges including high turnover, a weak financial base and a shortage of professional staff (Suzuki, 2008; Weathers, 2010). The possibilities to organize employees in unionised workplaces are also limited by the prevalence of enterprise unionism and union shop agreements. As a consequence, these unions account for less than one per cent of total union membership (Oh, 2012; Royle and Urano, 2012; Weathers, 2010). Despite this relative weakness, community unions support individual workers through services in labour consultation and dispute resolution and provide visibility to the problems of precarious employment, often through a strong media presence (Oh 2012; Royle and Urano, 2012).

This discussion explains the limited achievements by Japanese unions in organizing nonregular workers and the challenges they face in doing so. It not only illustrates the potential importance of the current initiatives but also informs the article's two core questions. First, to what extent has the inclusion of non-regular employees changed the aforementioned characteristics of these unions? Secondly, to what extent have these initiatives improved the position of non-regular employees? The answers to these questions will decide to what extent unions have been able to overcome the dualism in the labour market and its implications for employment conditions.

\section{Study design}

This article draws on an ongoing study among Japanese unions and their strategies towards nonregular workers through semi-structured interviews with representatives of the two main national confederations, Rengo and Zenroren, and affiliated industrial and enterprise unions. However, this article solely addresses developments within Rengo - dominant in terms of membership size - and in particular the industrial federation UA Zensen and its affiliated enterprise unions. UA Zensen is the industrial union within Rengo for the commerce, distribution and retail industry and the result of a merger in November 2012 between UI Zensen and JSD. As of March 2016, over 56 per cent of the 1.64 million members of its affiliated unions were non-regular employees and this accounted for 
more than 80 per cent of all non-regular union members in Japan (see Table 2 in the next section). It includes contract and agency workers but almost completely concerns part-time workers and the remainder of this article will therefore refer to the latter when discussing these initiatives. These part-time workers tend to be employed through annual contracts although repeated renewals create an expectation of continuous employment in accordance with the Labour Standards Act (Nakakubo, 2004).

The respondents included representatives of relevant Rengo departments (i.e. Department of Organizational Affairs, Department of Non-regular Employment), the industrial federation UA Zensen and its predecessor UI Zensen, and three affiliated enterprise unions at major supermarket chains varying in size from about 20,000 to 90,000 employees. The enterprise unions at these firms here anonymised as RetailCo1, RetailCo2 and RetailCo3 - have organized non-regular workers from respectively 2006, 2006 and 2004. Initial interviews were organized through support from Japanese academic colleagues and two representatives of Rengo's Research Institute for Advancement of Living Standards (RENGO-RIALS) were present during some interviews and contributed occasionally. The majority of interviews took place in 2014 but earlier interviews in 2007 and 2011 inform a more long-term perspective. When relevant, the ongoing accuracy of earlier responses was confirmed during later interviews. Overall, this article draws on 10 interviews with 16 interviewees, of which four were interviewed on two different occasions. The shortest interview was 80 minutes but the majority of interviews lasted around 2 hours. Table 1 provides an overview of all the interviews together with their date and reference for citations. Repeat interviews with the same representative are indicated by the addition of $A$ or $B$ to the reference. All interviews were recorded and transcribed verbatim. Two interviews were in English but the others were predominantly in Japanese with an interpreter present to translate questions and answers when necessary. Where relevant, the citations included here were translated by the interpreter during the interview or have been translated afterwards. The study also draws on union documents received during the interviews 
including policy briefings, convention reports, specific reports on non-regular workers and 'manuals' for members and affiliated enterprise unions.

TABLE 1 here

The interview transcripts were analysed using a thematic analysis (King, 2004). Interview topics and questions provided an initial basis for coding but additional themes and subthemes were arrived at through an iterative process; first by analysing the interview transcripts and additional documents and subsequently by linking its outcomes to the research questions and literature. This approach allowed the flexibility to interpret emergent themes and capture the perspectives of union representatives but also ensured that findings were placed within the comparative literature on the organization of non-regular workers.

The discussion has a number of limitations. A first is intentional and concerns a focus on the initiatives by Rengo and in particular UA Zensen and its affiliated enterprise unions. As such, it offers a complement rather than an alternative to the relatively extensive literature on Japanese community unions (e.g. Broadbent, 2008; Oh, 2012; Stewart, 2006; Urano and Stewart, 2007, 2009; Weathers, 2010). Another limitation concerns the existence of any conflicts internal to the union which are only touched upon. Similarly, the voices of union members are not included here. Representatives were very positive about the union engagement by part-time members, especially as they are not affected by the geographical relocation (tenkin) that characterizes the careers of regular employees, but this deserves further study.

\section{The recruitment of part-time workers}

Rengo and its enterprise unions are 'sometimes regarded as the union only for the members of the big companies and male workers' (R13). Since 2001, however, Rengo developed various 'Action Plans' to improve the position of non-regular workers after it decided to push for an increase in the 
hourly wage of part-timers (R4A). In 2006 it established the Non-regular Joint Struggle Council to coordinate collective bargaining on behalf of non-regular workers across the affiliated unions. The Department of Non-regular Employment was established one year later to respond to collaborate with relevant NGOs in responding to social problems such as the rise in working poor. However, since 2010 it focused on the inclusion of non-regular workers at organized workplaces under the slogan 'let's start from the workplace' ('shokunōba kara hajimeyō') (R12). This change in strategy was explained by the impact of the 2008 economic crisis when many non-regular employees at Rengo organized workplaces lost their job. However, the challenges to collaborate with external organizations and the success of affiliated unions in organizing non-regular workers might arguably have influenced this decision as well.

The latter point reflects the fact that the main numerical success in organizing non-regular workers was achieved by UA Zensen and its affiliated unions (see Table 2). Representatives ascribed this success to the character of the former UI Zensen as more centralised than other federations and thus with stronger leadership over its enterprise unions. Centralization was enforced through an 'integrated struggle' (R9) which requires the affiliated enterprise unions to consult with UI Zensen before initiating a strike or agreeing a wage settlement. Representatives also ascribed the success to an 'organizing culture' which developed when the union started to organize workers who were dispatched from apparel companies to department stores in the 1970s and 1980s (R1A). However, the strategies have been controversial. Critics have referred to organizing campaigns that are topdown, stress coordination with management rather than the involvement of workers and undercut other, more independent and critical, unions (Weathers, 2007).

TABLE 2 here

The strong rise in non-regular membership started in the 2000s when enterprise unions at major supermarkets decided to organise part-time workers. In accordance with UA Zensen's strong 
coordination, the strategies of the three enterprise unions included here are very similar and the discussion will therefore present the findings across case-studies rather than on a case-by-case basis. The unions accepted all part-timers working over 20 hours per week as they were considered to deserve greater equality in employment conditions because of their increasing roles and responsibilities. However, the organization of part-timers was mostly a direct and instrumental response to their rising share of total employment. As consistently confirmed by representatives, both male and female, considerations of gender played little role in the decision to organize parttime workers in spite of the large majority of female workers: I'm afraid that we don't think about the gender point of view' (R8).

Cooperation with management characterized this inclusion of part-time workers within the union. As expressed by a representative, it was the firm that 'decided to break the wall between regular and non-regular workers, and started to treat both of them equally' (R9). The unions can therefore be argued to have followed management: 'Because of this changing of system, we decided to invite non-regular workers to the union' (R9). Representatives of all three enterprise unions also stated how management supported the unionization of non-regular workers for various reasons. First of all, it guaranteed a continuation of the union's position as a majority union, which enables the extension of collective agreements to cover all employees and reduces the likelihood of entry by more critical unions. Moreover, firms also saw the union as means to access opinions, complaints and grievances, and to consult workers when introducing new schemes or systems. Union representatives also stressed the potential contribution of unionization to the success of the firm. For example, a written response by the representatives of the RetailCo3 enterprise union listed objectives such as 'the improvement of productivity' and 'the development of human resources'.

Representatives of the enterprise unions estimated that over 90 per cent of invited parttimers had become members. The close cooperation with management and the inclusion of parttime workers in union shop agreements contributed to this success albeit with an important caveat. A union shop agreement can only apply to newly hired employees and existing employees had to be 
actively recruited. With strong support from management, representatives of all enterprise unions carried out extensive promotion activities at each shop to approach workers, often with help from regular union members. The union representatives also ascribed the success in recruitment to workers' disposition to be a part of the organization: 'employees want to create something together... they want to do something together' (R10). Finally, part-time workers were argued to consider unionization as a means to strengthen their position within the firm:

If we look at the historical development of the Japanese labour movement, workers sought the protection of the union so that status can be guaranteed. There is something in their mentality that by joining the union, their standing or social status will be guaranteed (RES1).

\section{The representation of part-time workers}

The unionization of part-time workers resulted in the representation of rights previously exclusive to regular workers. For example, unions supported the management of so-called 'human relations' between managers and their subordinates in case of sexual or power harassment and conflicts about paid leave. Unionization also gave members access to various discounts that are available through cooperation between the firm and the enterprise union and certain insurances (kyōsai) provided by either the enterprise union or UA Zensen. The main issues, however, concerned employment and wages. First and foremost, in accordance with its importance among regular employees, was employment security. Union members qualified for transfer to another store or a redundancy payment in case of store closure. Unionization also enabled the inclusion of non-regular with regular workers in the negotiation of working conditions during the in the annual shunto collective bargaining, a major development as conditions for non-regular workers used to be set unilaterally by management and tended to be 'vague' and 'prone to confusion' (Morozumi, 2009: 42).

All three enterprise unions also contributed to their firm's introduction of new personnel systems that offer greater career and pay opportunities to non-regular workers, including the 
possible transfer from non-regular to regular employment and vice versa. Although firms had slowly introduced some differentiation in the wages of non-regular workers from the 1990s, these developments were tentative and the implications were minor. The firms' new personnel systems were developed with strong involvement of the union as confirmed by a representative of the RetailCo1 union: 'We held a lot of meetings at the company, at the union office; sometimes we stayed overnight. This is not a system just established by the company but the union also made proposals, suggestions' (R2). All representatives considered these systems crucial to improve the position of non-regular workers. First, to better define their responsibilities and rights, and secondly to ultimately demand a system 'where regular and non-regular workers are given fair and equal treatment, especially for similar work' (R1A). This representative argued as follows:

If non-regular workers perform more difficult jobs that regular workers do as well, then they have to get equal pay. However, at this moment, many companies don't have a personnel system for part-time employees. They do not have an ability qualification system for parttime workers. Without such a system it is very difficult to get an increase in the wages of part-time workers... If we make those systems, it is easier to say when equality is there (R1A).

At the same time, the improvements offered by the new career trajectories were debatable. Only a limited number of workers were promoted with a large majority remaining in 'standard' part-time positions. The implications in terms of pay are beyond the scope and focus of this article because of the large number of determining factors, including various allowances (e.g. area, children's education, housing, commuting) and extra pay for unsocial hours (holiday work, overtime, late night work). However, all representatives acknowledged that improvements in pay were constrained by one's position as non-regular worker. Part-time and regular workers may perform similar jobs but the careers in which these jobs are embedded were perceived as fundamentally different and the 
principle of 'equal-pay-for-equal-work' was therefore difficult to implement. For example, in contrast to their regular colleagues, non-regular employees had set working hours and were not expected to work overtime without pay. One UA Zensen representative described the challenge as follows:

Wages are different, bonuses are different, retirement pay is different. Almost all labour conditions are different. The union tries for improvement for both groups, but it is not equal. We try to make equal but we also think that we need some difference between non-regular and regular workers because they do not do the same job (R1A).

These considerations illustrate how difficult it was for unions to define, let alone promote, equality between regular and non-regular employment; especially given their entrenched commitment to regular employees. Both UA Zensen and Rengo considered the inclusion of part-time workers a means to achieve 'equilibrium and fairness compared to the treatment and the conditions for the regular workers' (R5). However, they largely accepted the secondary position of non-regular employees. Representatives acknowledged an ongoing debate within the union on the need for additional compensation for non-regular workers but this had not informed an explicit position on the differences in working conditions. Instead, they often referred to, or hid behind, the relative content of many part-time workers with estimates that about 80 per cent of all part-time employees preferred a 'standard' part-time position and had no ambition to move higher on the job ladder. This relative satisfaction, albeit clearly informed by the available options in the labour market, was confirmed by an actual decline in the share of Japanese workers in non-regular employment because they could not find regular employment from 25.8 per cent in 2004 to 18.1 per cent in 2014 . The respective data for part-time workers were 21.6 and 11.7 per cent (General Survey on Diversified Employment Types). One of the representatives expressed the complexity of the argument as follows: 
There are some...who say that in order to achieve equal treatment for the part-time workers; they need to be given higher wage increase. However, it is not that cut and dry. Because in the Japanese tax system, there are some people who don't want to earn more. People with such views are also part of this discussion. So it is not that simple to say that higher wages are needed, there are many factors in play here (R5).

\section{Discussion}

The previous sections have shown how unions have succeeded in raising their membership through strategies of 'external organizing' (Hurd, 2004) aimed at the largely unrepresented group of nonregular and in particular part-time workers. These initiatives are inclusive in scope (Heery, 2002) and unions have overcome their exclusive commitment to regular workers (e.g. Jeong and Aguilera, 2008; Urano and Stewart, 2007; Weathers, 2010). Non-regular workers now constitute the majority of members within UA Zensen and in each of the three enterprise unions. Moreover, their position has been strengthened, in particular through their representation in the annual shuntō, the greater career and pay opportunities and the potential transfer between non-regular and regular employment. These are important achievements, especially for those part-timers who are 'breadwinners' and in fundamental need of higher levels of income. However, several factors have limited changes to both the character of Japanese unions and the secondary position of non-regular workers in the labour market.

The impact on Japanese unionism has been limited by the top-down character of the organizing initiatives. An important underlying factor concerns the main parties responsible for the changes (Heery, 2005), namely the national leadership of Rengo and UA Zensen following the decision by employers to increase the share of non-regular employment. It confirms the need to distinguish the main parties responsible for change (Heery, 2005). In particular the strong coordination by UA Zensen has resulted in a rather homogeneous implementation of strategies 
across enterprise unions with few adjustments to the specific organizational context or workers concerned. Moreover, the existing 'partnership' relation as defined by strong cooperation at the enterprise level means that the initiatives have been introduced in coordination with management. Japanese unions appear rather unique in this respect and one could argue that management has had a stronger voice in shaping the organizing practices than the non-regular workers concerned. Recruitment of members also continues to be 'enforced' by union shop agreements and the main form of representation has taken place through the firms' new personnel systems.

These observations not only confirm the continued relevance of former criticism (Weathers, 2007). They also imply that the organizing initiatives did not have a 'transformative' effect on the trade unions' internal debate and practices as has been observed - albeit it with limits and constraints - in other contexts, including those characterized by institutionalised social partnership (Connolly et al., 2017). There has been little change towards 'internal organizing' through greater member mobilization and the rediscovery of the union as social movement (Heery, 2002; Hurd, 2004). Gender considerations, for instance, have played little role in spite of the over-representation of women among part-time employees. The shift of policy in 2010 away from collaborations with relevant NGOs to the inclusion of non-regular workers at organized workplaces is also illustrative in this respect. It confirms how the changes were primarily informed by the need of both management and the union to guarantee the functioning of previous institutionalised procedures and practices that were put at risk by the rise in non-regular employment. It suggests that organizing strategies have been used primarily as instrument to support the status quo rather than to promote union renewal.

The impact on the position of non-regular workers is in accordance and constitutes a second important limitation of the current initiatives. As mentioned, the new inclusive personnel systems have improved potential career trajectories in a situation where the principle of 'equal-pay-forequal-work' is difficult to implement. However, they also offered a means to 'absorb' the inequalities as defined by the dualism in the labour market rather than a challenge to its underlying 
mechanisms. Firms have created new career opportunities but also upheld the distinctions between different groups that constitute the cost advantages offered by non-regular employment. Union identity has shaped objectives and strategies (Hodder and Edwards, 2015) as cooperative enterprise unions have largely accepted the status quo in the labour market and have not developed a strong stance for the emancipation of non-regular workers. It explains why the inclusion has been largely limited to contract and part-time workers who can be rather easily included in the firm community because of their stable employment, and has excluded more precarious types of employment. Japanese unions may prefer to protect all workers but their enterprise-based character almost by definition implies a distinction between insiders and outsiders.

These findings both draw upon and contribute to the comparative debates on organizing and the unionization of non-regular workers. The top-down character of these initiatives mirrors findings in other countries (e.g. Connoly et al., 2017; De Tuberville, 2004) where organizing has been 'used to buttress existing hierarchies of power within unions' (Carter, 2006: 415) in spite of claims that worker self-organization must 'be integral to our understanding of' organizing (Simms and Holgate, 2010: 165). It encourages further reflection on the political purpose of 'innovations' when wider representation becomes functional to maintaining the balance of power and the functioning of existing industrial relations rather than an aim in itself. The findings also confirm how labour market structures, especially as segmented as in Japan, may allow for more inclusive recruitment but severely constrain the development of wider solidarities and material equality (e.g. Cockburn, 1989; Simms, 2012). Following Hyman's (1997) analytical distinction between the who, what and how of interest representation, we can conclude that Japanese unions have changed their constituency but not the type of interests they promote and, in particular, how these interests are promoted. This limits the potential improvements to the position of non-regular workers and suggests that without coherent changes to all three aspects, any transcendence beyond the representation of regular employees remains 'partial' (Hyman, 1997: 520). In accordance, further progress will require Japanese unions to recognize the limitations of the current enterprise-based 
system and to develop wider solidarities by more strongly engaging with different interests. However, the relative failure of community unions to increase their membership illustrates the challenge to do so in the context of labour market dualism and the existing system of industrial relations.

\section{Conclusions}

Previous criticism against the unwillingness of mainstream unions in Japan to address the dualism in the labour market has been well justified given their exclusive commitment to regular employees. However, the article has shown how certain unions have been able to organize non-regular workers in spite of earlier expectations to the contrary. As a consequence, Rengo has managed to halt the long-time decline in its membership while UA Zensen (including the pre-merger UI Zensen and JSD) has achieved a truly impressive rise in membership of 50 per cent over the ten years up to 2016. Important concerns remain though about the impact of the initiatives. The unions concerned may have widened their constituency but have not changed their relationship with members or their modus operandi. In accordance, they have been unable to fundamentally address the existing inequality between regular and non-regular employment. It illustrates the continued need for alternative structures such as community unions. Concerns also exist whether these initiatives can be extended as they have been limited to industries and enterprises where rising numbers require that certain non-regular workers are re-classified from the 'periphery' to the 'core'. It is significant that UA Zensen affiliated enterprise unions at manufacturing firms, much less dependent on nonregular employment, have hardly organized these workers. UA Zensen also remains an exception in its strong control over its enterprise unions and the relative inability of industrial and national federations in Japan to shape actions remains a major constraint, not just for successful coordination across enterprise unions but also for the development of wider solidarities at the sectoral and national level (Hyman, 1999; Simms, 2012). This mirrors conclusions on the challenges to organize non-regular workers at the enterprise level by European studies (Heery, 2009; Keune, 2013). Finally, 
the lack of enterprise unions at small- and medium-sized companies poses another obvious challenge to the further organization of non-regular workers.

The findings confirm how both ideological and institutional factors matter. Unions are strongly embedded within the labour market and society, and this influences their strategies and limits their ability to instigate progressive change; something that is often not acknowledged by highly critical analyses such as Standing (2011). The current dualism, characterized by high demands on much regular employment and limited pay and progression for non-regular employment, creates a deadlock that can only be overcome by a concerted effort. As long as unions remain committed to the existing employment practices that define the unique position of regular workers, the ability to argue for material equality remains constrained. However, they are unlikely to shed this ideology without any prospects that this may contribute to a stronger position for both unions and workers. Substantial change will therefore require the support for equality by others like firms (e.g. because of a shortage of employees) and the state (e.g. because of concerns about (gender) inequality and working poor). In addition, it will require that part-time workers demand greater equality. In the short run the precarious position of so-called 'breadwinner part-timers' may be important. In the long run the privileged position of regular employees and the gendered nature of employment are at stake.

\section{Acknowledgements}

I gratefully acknowledge the feedback by Stefania Marino, Miguel Martínez Lucio, Yoshihide Sano and Atsushi Sato on earlier drafts of this article. I also like to thank the editor and anonymous reviewers for their valuable comments.

\section{Funding}


This research was made possible by funding from the Japan Institute for Labour Policy and Training (JILPT) and the Canon Foundation in Europe.

\section{References}

Allison A (2012) A sociality of, and beyond, 'my-home' in post-corporate Japan. Cambridge Anthropology 30(1): 95-108.

Baccaro L, Hamann K and Turner L (2003) The politics of labour movement revitalization: the need for a revitalized perspective. European Journal of Industrial Relations 9(1): 119-133.

Benassi C and Dorigatti L (2015) Straight to the core - explaining union responses to the casualization of work: the IG Metall campaign for agency workers. British Journal of Industrial Relations 53(3): 533-555.

Broadbent K (2008) Japan: women workers and autonomous organizing. In: Broadbent K and Ford M (eds) Women and Labour Organizing in Asia: Diversity, Autonomy and Activism. London: Routledge, 156-171.

Carter B (2000) Adoption of the organizing model in British trade unions: some evidence from manufacturing, science and finance (MSF). Work, Employment and Society 14(1): 117-136.

Carter B (2006) Trade union organizing and renewal: a response to De Turberville. Work, Employment and Society 20(2): 415-426.

Cockburn C (1989) Equal opportunities: the short and long agenda. Industrial Relations Journal 20(4): 213-225.

Connolly H, Marino S and Martínez Lucio M (2017) 'Justice for janitors' goes Dutch: the limits and possibilities of unions' adoption of organizing in a context of regulated social partnership. Work, Employment and Society 31(2): 319-335.

De Turberville S (2004) Does the 'organizing model' represent a credible union renewal strategy? Work, Employment and Society 18(4): 775-794. 
Frege CM and Kelly J (2003) Union revitalization strategies in comparative perspective. European Journal of Industrial Relations 9(1): 7-24.

Gadrey J, Jany-Catrice F and Ribault T (2001) Levels and systems of employment in the Japanese retail trade: a comparison with France. Cambridge Journal of Economics 25(2): 165-184.

Gottfried H and Hayashi-Kato N (1998) Gendering work: deconstructing the narrative of the Japanese economic miracle. Work, Employment and Society 12(1): 25-46.

Grimshaw D, Johnson M, Rubery J and Keizer A (2016) Reducing Precarious Work: Protective Gaps and the Role of Social Dialogue in Europe. Available at:

http://www.research.mbs.ac.uk/ewerc/Portals/O/Documents/Comparative-Report-ReducingPrecarious-Work-v2.pdf (accessed 21 December 2016).

Gumbrell-McCormick R (2011) European trade unions and 'atypical' workers. Industrial Relations Journal 42(3): 293-310.

Gumbrell-McCormick R and Hyman R (2013) Trade Unions in Western Europe: Hard Times, Hard Choices. Oxford: OUP.

Heery E (2002) Partnership versus organising: alternative futures for British trade unionism. Industrial Relations Journal 33(1): 20-35.

Heery, E (2005) Sources of change in trade unions. Work, Employment and Society 19(1): 91-106.

Heery E (2009) Trade unions and contingent labour: scale and method. Cambridge Journal of Regions, Economy and Society 2: 429-442.

Hodder A and Edwards P (2015) The essence of trade unions: understanding identity, ideology and purpose. Work, Employment and Society 29(5): 843-854.

Hurd R (2004) The failure of organizing, the new unity partnership, and the future of the labor movement. Working USA: The Journal of Labour and Society 8: 5-25.

Hyman R (1997) Trade unions and interest representation in the context of globalisation. Transfer 3: $515-533$. 
Hyman R (1999) Imagined solidarities: can trade unions resist globalisation? In: Leisink P (ed.) Globalization and Labour Relations. Cheltenham: Edward Elgar.

Hyman R (2001) Understanding European Trade Unionism: Between Market, Class and Society. London: Sage.

Imai J (2011) The Transformation of Japanese Employment Practices: Reform Without Labour. Basingstoke: Palgrave Macmillan.

JILPT [Japan Institute for Labour Policy and Training] (2005) Pa-to taimū to seishain no kinkō shogū. Rōdō seisaku kenkyū hōkokusho, 34.

JILPT [Japan Institute for Labour Policy and Training] (2016) The Labor Situation in Japan and its Analysis: General Overview 2015/2016. Tokyo.

Jeong DY and Aguilera RV (2008) The evolution of enterprise unionism in Japan: a socio-political perspective. British Journal of Industrial Relations 46(1): 98-132.

Keizer AB (2008) Non-regular employment in Japan: continued and renewed dualities. Work, Employment and Society 22(3): 407-425.

Keizer AB (2010) Changes in Japanese Employment Practices: Beyond the Japanese Model. London: Routledge.

Keune M (2013) Trade union responses to precarious work in seven European countries. International Journal of Labour Research 5(1): 59-78.

King N (2004) 'Template Analysis'. In: Cassell CM and Symon G (eds) Essential Guide to Qualitative Methods in Organizational Research. London: Sage, 118-134.

Locke RM and Thelen K (1995) Apples and oranges revisited: contextualized comparisons and the study of comparative labor politics. Politics and Society 23(3): 337-367.

Marino S (2012) Trade union inclusion of migrant and ethnic minority workers: an Italy-Netherlands comparison. European Journal of Industrial Relations 18(5): 5-20.

Morozumi M (2009) Balanced treatment and bans on discrimination: significance and issues of the revised Part-Time Work Act. Japan Labor Review 6(2): 39-55. 
Nagase N (2003) Standard and nonstandard work arrangements, pay difference and choice of work by Japanese mothers. In: Houseman S and Osawa M (eds) Nonstandard Work in Developed Economies. Kalamazoo: W.E. Upjohn Institute for Employment Research, 267-305.

Nakakubo H (2004) The 2003 revision of the Labour Standards Law: fixed-term contracts, dismissal and discretionary-work schemes. The Japan Labor Review 1(2): 4-25.

Oh H-S (2012) The current status and significance of general unions: concerning the resolution of individual labor disputes. Japan Labor Review 9(1): 63-85.

Palier B and Thelen K (2010) Institutionalizing dualism: complementarities and change in France and Germany. Politics Society 38(1): 119-148.

Passet O (2003) Stability and change: Japan's employment system under pressure. In: Auer P and Cazes S (eds) Employment Stability in an Age of Flexibility: Evidence from Industrialized Countries. Geneva: ILO, 159-217.

Pulignano, V, Meardi G and Doerflinger N (2015) Trade unions and labour market dualisation: a comparison of policies and attitudes towards agency and migrant workers in Germany and Belgium. Work, Employment and Society 29(5): 808-825.

Royle T and Urano E (2012) A new form of union organizing in Japan? Community unions and the case of the McDonald's 'McUnion'. Work, Employment and Society 26(4): 602-622.

Rueda D (2005) Insider-outsider politics in industrialized democracies: the challenge to social democratic parties. American Political Science Review 99(1): 61-74.

Simms, M (2012) Imagined solidarities: where is class in union organising? Capital and Class 36(1): $97-115$.

Simms $M$ and Holgate J (2010) Organising for what? Where is the debate on the politics of organising? Work, Employment and Society 24(1): 157-168.

Standing G (2011) The Precariat: The New Dangerous Class. London: Bloomsbury Academic.

Stewart P (2006) Marginal movements and minority struggles? The case of the Japanese minority social and labour movements. The Sociological Review 54(4): 753-773. 
Suzuki H (2004) Enterprise unionism in crisis in Japan. ESAN Cuadernos de Diffusión 16: 7-19.

Suzuki A (2008) Community unions in Japan: similarities and differences of region-based labour movements between Japan and other industrialized countries. Economic and Industrial Democracy 29(4): 492-520.

Tachibanaki T and Noda T (2000) The Economic Effects of Trade Unions in Japan. London: Macmillan. Tsuchida M (2004) Career formation and balanced treatment of part-time workers: an examination focusing on legal policy. Japan Labor Review 1(4): 27-47.

TUC (2008) Hard Work, Hidden Lives: The Full Report of the Commission on Vulnerable Employment. Urano El and Stewart P (2007) Including the excluded workers? The challenges of Japan's Kanagawa City union. The Journal of Labour and Society 10: 103-123.

Urano El and Stewart P (2009) Beyond organised labour in Japan: the case study of the Japanese Community Union Federation. In: McBride J and Greenwood I (eds) Community Unionism: A Comparative Analysis of Concepts and Contexts. Basingstoke: Palgrave Macmillan, 121-138.

Weathers C (2007) Organizing marginalized and non-regular workers: a US-Japan comparison. Discussion Paper No. 4. Osaka City University: Center for Research on Economic Inequality.

Weathers C (2010) The rising voice of Japan's community unions. In: Vincken H, Nishimura Y, White $\mathrm{B} \sqcup$ and Deguchi M (eds) Civic Engagement in Contemporary Japan: Established and Emerging Repertoires. New York: Springer, 67-83.

Yun J-W (2010) Unequal Japan: conservative corporatism and labour market disparities. British Journal of Industrial Relations 48(1): 1-25.

\section{Author biography}

Arjan Keizer is lecturer in international HRM and comparative industrial relations at the University of Manchester. Important topics in his comparative research on employment practices and relations include processes of change in national employment systems, precarious employment and labour market dualism, unions and social dialogue, institutional theory and convergence. Publications on 
Japan include journal articles, book chapters and Changes in Japanese Employment Practices: Beyond the Japanese Model (Routledge). 
1

2

3

4

5

6

7

8

9

10

11

12

13

14

15

16

17

18

19

20

21

22

23

24

25

26

27

28

29

30

31

32

33

34

35

36

37

38

39

40

41

42

43

44

45

46

47

48

49

50

51

52

53

54

55

56

57

58

59

60

Table 1. Overview interviews

\begin{tabular}{|l|l|}
\hline Date & Organization and representatives \\
\hline $03 / 10 / 2007$ & Representative UI Zensen (R1A) \\
\hline $25 / 10 / 2007$ & 2 representatives Union RetailCo 1 (R2, R3) \\
\hline $05 / 12 / 2007$ & Representative Rengo Department of Non-regular Employment (R4A) \\
\hline $23 / 02 / 2011$ & Representative UI Zensen (R1B) \\
\hline $13 / 05 / 2014$ & 3 Representatives UA Zensen (R5, R6, R7A), Senior Researcher RENGO-RIALS (RES1A) \\
\hline $06 / 06 / 2014$ & $\begin{array}{l}\text { Former representative Rengo Department of Non-regular Employment (R4B), Senior } \\
\text { Researcher RENGO-RIALS (RES1B) }\end{array}$ \\
\hline $10 / 06 / 2014$ & Representative Union RetailCo2 (R8), Representative UA Zensen (R7B) \\
\hline $12 / 06 / 2014$ & 3 representatives Union RetailCo3 (R9, R10, R11) \\
\hline $13 / 06 / 2014$ & $\begin{array}{l}\text { Representative Rengo Department of Non-regular Employment (R12), Senior Researcher } \\
\text { RENGO-RIALS (RES2A) }\end{array}$ \\
\hline $17 / 06 / 2014$ & $\begin{array}{l}\text { 2 representatives Rengo Department of Organizational Affairs (R13, R14), Senior Researcher } \\
\text { RENGO-RIALS (RES2B) }\end{array}$ \\
\hline
\end{tabular}


Table 2. Data on unionization in Japan and by UA Zensen, UI Zensen and JSD

\begin{tabular}{|c|c|c|c|c|c|c|c|c|c|c|c|c|c|c|c|c|c|}
\hline & 2000 & 2001 & 2002 & 2003 & 2004 & 2005 & 2006 & 2007 & 2008 & 2009 & 2010 & 2011 & 2012 & 2013 & 2014 & 2015 & 2016 \\
\hline 'Short-term' union members $(x 1,000)^{1}$ & 260 & 280 & 292 & 331 & 363 & 389 & 515 & 588 & 616 & 700 & 726 & 776 & 837 & 914 & 970 & 1,025 & 1,131 \\
\hline 'Short-term' unionization rate (\%) ${ }^{1}$ & 2.6 & 2.7 & 2.7 & 3.0 & 3.3 & 3.3 & 4.3 & 4.8 & 5.0 & 5.3 & 5.6 & - & 6.3 & 6.6 & 6.7 & 7.0 & 7.5 \\
\hline Members UI Zensen $(x 1,000)^{1}$ & - & - & - & 794 & 800 & 832 & 888 & 981 & 986 & 1,031 & 1,058 & 1,069 & 1,086 & \multicolumn{4}{|c|}{$\mathrm{N} / \mathrm{A}$} \\
\hline Members JSD $(\times 1,000)^{1}$ & - & - & 181 & 184 & 184 & 193 & 206 & 212 & 216 & 219 & 231 & 230 & 248 & \multicolumn{4}{|c|}{$\mathrm{N} / \mathrm{A}$} \\
\hline Members UA Zensen $(x 1,000)^{1}$ & \multicolumn{13}{|c|}{ N/A } & 1,400 & 1,466 & 1,536 & 1,607 \\
\hline Members UI Zensen $(\times 1,000)^{2}$ & - & - & - & - & 826 & 862 & 948 & 1,002 & 1,036 & 1,071 & 1,093 & 1,093 & 1,162 & \multicolumn{4}{|c|}{ N/A } \\
\hline 'Short-term' members UI Zensen $(x 1,000)^{2}$ & - & - & - & - & 244 & 290 & 386 & 413 & 460 & 490 & 507 & 509 & 578 & \multicolumn{4}{|c|}{$\mathrm{N} / \mathrm{A}$} \\
\hline Members UA Zensen $(x 1,000)^{2}$ & \multicolumn{13}{|c|}{$\mathrm{N} / \mathrm{A}$} & 1,453 & 1,518 & 1,572 & 1,642 \\
\hline 'Short-term' members UI Zensen $(x 1,000)^{2}$ & \multicolumn{13}{|c|}{$\mathrm{N} / \mathrm{A}$} & 745 & 797 & 848 & 922 \\
\hline Share 'short-term' workers UI/UA Zensen (\%) & - & - & - & - & 29.5 & 33.7 & 40.7 & 41.2 & 44.5 & 45.8 & 46.4 & 46.6 & 49.7 & 51.2 & 52.5 & 53.9 & 56.2 \\
\hline
\end{tabular}

Notes: Short-term (tanjikan) union members include both part-time and contract workers with the former constituting the large majority.

Sources: ${ }^{1}$ Survey on Trade Unions Structure [Nen rōdō kumiai kiso chōsa no gaikyō]; ${ }^{2}$ Provided by UI/UA Zensen 